\title{
Synthesis of Zeolites in the Presence of Diquaternary Alkylammonium lons as Structure-Directing Agents
}

\author{
P. Caullet ', J.-L. Paillaud', Y. Mathieu' and N. Bats ${ }^{2 *}$ \\ 1 Laboratoire de Matériaux à Porosité Contrôlée, UMR CNRS 7016, ENSCMu, UHA, 3 rue Alfred Werner, 68093 Mulhouse Cedex - France \\ 2 Institut français du pétrole, IFP-Lyon, Rond-point de l'échangeur de Solaize, BP 3, 69360 Solaize - France \\ e-mail: Philippe.Caulle@@uha.fr - Jean-Lovis.Paillaud@uha.fr - Yannick.Mathieu@uha.fr - Nicolas.Bats@ifp.fr \\ * Corresponding author
}

Résumé - Synthèse de zéolithes en présence de cations alkyldiammonium quaternaires comme agents structurants - Cet article présente les résultats de synthèses réalisées pour la plupart en milieu purement silicique, en présence de cations $\left(\mathrm{CH}_{3}\right)_{3} \mathrm{~N}^{+}\left(\mathrm{CH}_{2}\right)_{n} \mathrm{~N}^{+}\left(\mathrm{CH}_{3}\right)_{3}(n=5,6,9$ ou 10) en milieu fluoré, mais également en présence de cations $\left(\mathrm{CH}_{3}\right)_{3} \mathrm{~N}^{+}\left(\mathrm{CH}_{2}\right)_{n} \mathrm{O}\left(\mathrm{CH}_{2}\right)_{n} \mathrm{~N}^{+}\left(\mathrm{CH}_{3}\right)_{3} \quad(n=2$ or 4) en milieu hydroxyde ou fluoré. Dans ces conditions, de nombreuses structures zéolithiques différentes ont été préparées telles que la zéolithe ZSM-48, des zéolithes de type structural MTW, BEA, MFI ou ITH. Dans certains cas, il a été observé une forte dégradation de l'espèce structurante en $\mathrm{N}\left(\mathrm{CH}_{3}\right)_{4}{ }^{+}$ou $\mathrm{N}\left(\mathrm{CH}_{3}\right)_{3}$, ce qui a conduit à l'obtention de zéolithes de type AST, MTN et RUT. Les échantillons obtenus ont été caractérisés par DRX, MEB analyses thermiques et élémentaire, $\mathrm{RMN}{ }^{1} \mathrm{H}$ liquide (après dissolution de l'échantillon dans une solution aqueuse d'acide fluorhydrique) ainsi que par RMN du solide $\left({ }^{19} \mathrm{~F},{ }^{13} \mathrm{C},{ }^{27} \mathrm{Al}\right)$.

\begin{abstract}
Synthesis of Zeolites in the Presence of Diquaternary Alkylammonium Ions as StructureDirecting Agents - This paper deals with the synthesis results obtained mostly from pure silica systems in the presence of $\left(\mathrm{CH}_{3}\right)_{3} \mathrm{~N}^{+}\left(\mathrm{CH}_{2}\right)_{n} \mathrm{~N}^{+}\left(\mathrm{CH}_{3}\right)_{3}$ ions $(n=5,6,9$ or 10) in fluoride media, but also in the presence of $\left(\mathrm{CH}_{3}\right)_{3} \mathrm{~N}^{+}\left(\mathrm{CH}_{2}\right)_{n} \mathrm{O}\left(\mathrm{CH}_{2}\right)_{n} \mathrm{~N}^{+}\left(\mathrm{CH}_{3}\right)_{3}$ ions $(n=2$ or 4$)$ in hydroxide or fluoride media. $\mathrm{A}$ variety of zeolites form, namely ZSM-48, MTW-type, BEA-type, MFI-type, ITH-type zeolites, but also,

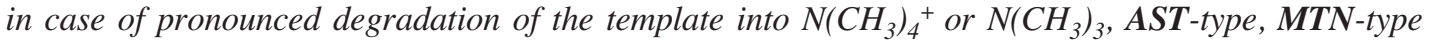
and $\boldsymbol{R} \boldsymbol{U} \boldsymbol{T}$-type materials. The samples are characterized by XRD, SEM, thermal and elementary analyses, ${ }^{1} \mathrm{H}$ liquid NMR (after dissolution of the sample in HF aqueous solution) and solid-state NMR $\left({ }^{19} \mathrm{~F},{ }^{13} \mathrm{C},{ }^{27} \mathrm{Al}\right)$ spectroscopy.
\end{abstract}




\section{INTRODUCTION}

The use of diquaternary alkylammonium ions with the general formula $\mathrm{R}_{3} \mathrm{~N}^{+}\left(\mathrm{CH}_{2}\right)_{n} \mathrm{~N}^{+} \mathrm{R}_{3}$ as structure directing agents (SDAs) has been widely reported, leading to a variety of zeolites, depending in particular on the length of the polymethylene chain, the nature of the $\mathrm{R}$ alkyl group, but also on the nature of the framework atoms or of the mobilizing $\left(\mathrm{OH}^{-}\right.$or $\left.\mathrm{F}^{-}\right)$agent [1-15].

This paper deals with the synthesis of zeolites in the presence of $\left(\mathrm{CH}_{3}\right)_{3} \mathrm{~N}^{+}\left(\mathrm{CH}_{2}\right)_{n} \mathrm{~N}^{+}\left(\mathrm{CH}_{3}\right)_{3}$ ions with $n=5,6,9$ or 10 in fluoride media, but also in the presence of $\left(\mathrm{CH}_{3}\right)_{3} \mathrm{~N}^{+}\left(\mathrm{CH}_{2}\right)_{n} \mathrm{O}\left(\mathrm{CH}_{2}\right)_{n} \mathrm{~N}^{+}\left(\mathrm{CH}_{3}\right)_{3}$ ions with $n=2$ or 4 in hydroxide or fluoride media. The use of the latter kind of SDAs, combining the 2 quaternary ammonium and ether chemical functions, was, to our knowledge, only once reported in the literature, leading to the formation of ZSM-11 in the presence of the 2,2-diethoxy-trimethylammonium cation [16]. Most syntheses are performed in purely silicic systems, a few experiments being also made in the additional presence of aluminium.

\section{EXPERIMENTAL SECTION}

$\left(\mathrm{CH}_{3}\right)_{3} \mathrm{~N}^{+}\left(\mathrm{CH}_{2}\right)_{n} \mathrm{~N}^{+}\left(\mathrm{CH}_{3}\right)_{3}$ (n-diquat) with $n=6,9$ or 10 are commercially available under their bromide form (Aldrich), whereas $\left(\mathrm{CH}_{3}\right)_{3} \mathrm{~N}^{+}\left(\mathrm{CH}_{2}\right)_{5} \mathrm{~N}^{+}\left(\mathrm{CH}_{3}\right)_{3} \mathrm{Br}$ is prepared by reaction of 1,5 dibromopentane with trimethylamine [17].

$\left(\mathrm{CH}_{3}\right)_{3} \mathrm{~N}^{+}\left(\mathrm{CH}_{2}\right)_{2} \mathrm{O}\left(\mathrm{CH}_{2}\right)_{2} \mathrm{~N}^{+}\left(\mathrm{CH}_{3}\right)_{3} \mathrm{Br}^{-}\left(\mathrm{BTMAEE}^{2+} \mathrm{Br}^{-}\right)$ and $\left(\mathrm{CH}_{3}\right)_{3} \mathrm{~N}^{+}\left(\mathrm{CH}_{2}\right)_{4} \mathrm{O}\left(\mathrm{CH}_{2}\right)_{4}-\mathrm{N}^{+}\left(\mathrm{CH}_{3}\right)_{3} \mathrm{Cl}^{-}\left(\mathrm{BTMABE}^{2+} \mathrm{Cl}^{-}\right)$ are synthesized by reaction of trimethylamine with bis (2-bromoethyl) ether or bis (2-bromobutyl) ether [18]. The corresponding hydroxide forms are prepared by reaction with $\mathrm{Ag}_{2} \mathrm{O}$.

Silica sources are Aerosil 130 (unless otherwise specified) from Degussa in hydroxide media or tetraethoxysilane in fluoride media, alumina sources are $\mathrm{Al}(\mathrm{OH})_{3}$ (Reheis Ireland) or sodium aluminate (Carlo Erba) in hydroxide media or aluminium triisopropoxide in fluoride media.

Precursor gels are prepared as follows:

- dissolution in the required amount of water of the organic template source (halide or hydroxide) and possibly of the inorganic base $(\mathrm{NaOH})$;

- addition of the optional aluminium source, followed by 30 min stirring;

- addition of the silica source, followed by $45 \mathrm{~min}$ (hydroxide media) or $14 \mathrm{~h}$ (fluoride media) stirring;

- addition of HF aqueous solution, followed by $15 \mathrm{~min}$ stirring.

Zeolitic materials are prepared under hydrothermal conditions in Teflon lined stainless steel autoclaves under static or stirred conditions (stirring is performed by tumbling of the autoclave at about a $15 \mathrm{rpm}$ rate).
Synthesized products are recovered by filtration, washed with distilled water and finally dried overnight at $60^{\circ} \mathrm{C}$. Recovered solids are then caracterised by powder XRD (STOE STADI-P diffractometer, with linear position-sensitive detector, $\mathrm{Ge}$ monochromated $\mathrm{CuK} \alpha_{1}$ radiation), SEM (PHILIPS XL-30 microscope), TG/DSC (SETARAM LABSYS TG-DTA thermoanalyzer), solid state NMR (mainly ${ }^{19} \mathrm{~F}$, Bruker DSX 400 spectrometer), ${ }^{1} \mathrm{H}$ liquid NMR (after dissolution in a HF aqueous solution, Bruker Advance 400 spectrometer).

\section{RESULTS AND DISCUSSION}

\subsection{Syntheses in the Presence of the Bis ( $n$-Trimethylaminoalkyl)Ethers}

When BTMAEE ${ }^{2+} \mathrm{Br}^{-}$is used in hydroxide media (gel composition: $60 \quad \mathrm{SiO}_{2} ; 0-0.5 \quad \mathrm{Al}_{2} \mathrm{O}_{3} ; 10$ BTMAEE $(\mathrm{Br})_{2}$; 5-10 $\mathrm{Na}_{2} \mathrm{O} ; 2000-3000 \mathrm{H}_{2} \mathrm{O}$ ) in the $150-200^{\circ} \mathrm{C}$ temperature range for 1 to 15 days, a fast degradation of the SDA, probably through an Hoffmann's elimination reaction is observed. According to ${ }^{1} \mathrm{H}$ liquid NMR, the organic species present in the mother liquors as well as in the as-synthesized materials correspond to various mixtures of $\mathrm{BTMAEE}^{2+}$ derivatives, such as dimethylated or even monomethylated derivatives of this cation and also $\mathrm{N}\left(\mathrm{CH}_{3}\right)_{4}{ }^{+}$or $\mathrm{N}\left(\mathrm{CH}_{3}\right)_{3}$ species (spectra not shown). Table 1 describes the most representative syntheses performed in this system. From purely siliceous media, the obtention of pure ZSM-48 samples is only possible at 150 or $170^{\circ} \mathrm{C}$ under fast crystallisation conditions, i.e. in stirred systems and/or in the presence of seeds of ZSM-48 ( $2 \%$ versus silica weight, prepared by heating a gel of following composition $60 \mathrm{SiO}_{2} ; 5 \mathrm{RBr}_{2} ; 5 \mathrm{Na}_{2} \mathrm{O} ; 3000 \mathrm{H}_{2} \mathrm{O}$ at $200^{\circ} \mathrm{C}$ for 2 days, $\mathrm{R}$ being the hexamethonium cation $-\mathrm{HM}^{2+}-$, according to the procedure given by Giordano et al . [19]). Without seeds and in unstirred systems, the recovered products are made of kenyaite, amorphous phase, quartz and ZSM-48 zeolite (and also MTN-type material at $200^{\circ} \mathrm{C}$ ) in various proportions. Clearly the formation of ZSM-48 zeolite in the presence of the $\mathrm{BTMAEE}^{2+}$ cation is logical, considering the close morphological features of the $\mathrm{BTMAEE}^{2+}$ and $\mathrm{HM}^{2+}$ cations. Figures 1 and $2 \mathrm{a}, \mathrm{b}$ display respectively a typical X-ray diffractogramm and typical micrographs (acicular crystals) of pure ZSM-48 samples. According to TG/ATD experiments and elementary analyses, the amount of occluded organics corresponds to about one SDA per unit cell (48 $\mathrm{T}$ atoms), with a small amount of incorporated water (ca. 0.5 wt.\%) and sodium cations (ca. 0.4 ion per u.c.). The introduction of aluminium in the synthesis mixtures, even in low amounts, slows down the crystallisation rate and favours the co-crystallisation of the MTW-type zeolite (see Tab. 1). A pure $(\mathrm{Si}, \mathrm{Al}) \mathrm{ZSM}-48$ zeolite sample $(\mathrm{Si} / \mathrm{Al} \approx 120)$ could 
TABLE 1

Description of the most representative syntheses in hydroxide medium in the presence of $\mathrm{BTMAEE}^{2+}\left(60 \mathrm{SiO}_{2} ; x \mathrm{Al}_{2} \mathrm{O}_{3} ; 10 \mathrm{BTMAEE}(\mathrm{Br})_{2} ; 10 \mathrm{Na}_{2} \mathrm{O} ; 3000 \mathrm{H}_{2} \mathrm{O}\right)$

\begin{tabular}{|c|c|c|c|c|c|c|}
\hline Experiment No. & $x$ value & $\mathrm{T}\left({ }^{\circ} \mathrm{C}\right)$ & Time $(\mathrm{d})$ & Seeds* & $\begin{array}{l}\text { Synthesis } \\
\text { Conditions }\end{array}$ & $\begin{array}{c}\text { Products } \\
(\text { from XRD)** }\end{array}$ \\
\hline 1 & 0 & 170 & 7 & no & unstirred & $48+K+Q$ \\
\hline 2 & 0 & 170 & 2 & no & stirred & 48 \\
\hline 3 & 0 & 170 & 1 & yes & stirred & 48 \\
\hline 4 & 0 & 200 & 3 & no & stirred & $\mathrm{Q}+\mathbf{M T N}+48$ \\
\hline 5 & 0 & 150 & 7 & no & stirred & 48 \\
\hline 6 & 0.5 & 170 & 1 & yes & stirred & $\mathbf{M T W}+48+$ Am. \\
\hline 7 & 0.25 & 170 & 2 & yes & stirred & $48+$ MTW \\
\hline $8 * * *$ & 0.25 & 170 & 2 & yes & stirred & 48 \\
\hline
\end{tabular}

* ZSM-48 as-made crystals (2 wt.\% vs. silica).

** 48: ZSM-48 zeolite; MTW: MTW-type zeolite; MTN: MTN-type material; K: kenyaite; Q: quartz; Am.: amorphous phase).

*** Use of Aerosil 380 instead of Aerosil 130.

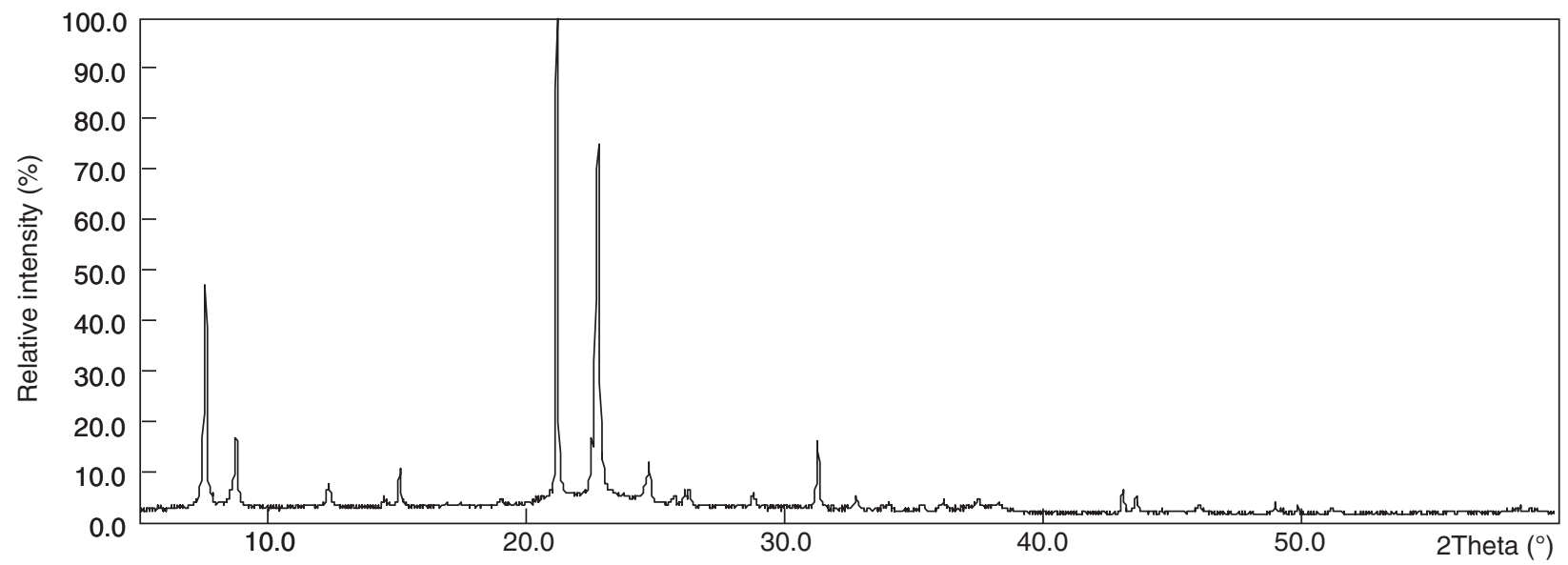

Figure 1

Powder X-ray diffraction pattern of ZSM-48 zeolite sample No. 2.

however be obtained from a gel with the same $\mathrm{Si} / \mathrm{Al}$ molar ratio in presence of seeds, in stirred system and using a more reactive silica source, Aerosil 380. The ${ }^{27} \mathrm{Al}$ MAS NMR spectrum (not shown) of the as-made ( $\mathrm{Si} / \mathrm{Al}$ ) ZSM-48 zeolite sample, displays a single signal at $48 \mathrm{ppm} / \mathrm{Al}\left(\mathrm{H}_{2} \mathrm{O}\right)_{6}{ }^{3+}$, characteristic of tetrahedrally coordinated aluminium.

Syntheses were also performed in fluoride media (gel composition: $1 \mathrm{SiO}_{2} ; 0-0.02 \mathrm{Al}_{2} \mathrm{O}_{3} ; 0.25 \mathrm{BTMAEE}(\mathrm{OH})_{2}$; 0.5-1 HF; 2-10 $\mathrm{H}_{2} \mathrm{O}$ ) and allowed the formation of the ASTtype clathrasil, the RUT-type zeolite (Si/Al 13) and again the ZSM-48 zeolite (see $T a b .2$ ). After 7 days at $170^{\circ} \mathrm{C}$, from purely siliceous mixtures, an amorphous phase or a mixture of ZSM-48 zeolite and AST-type material (prolongation of the synthesis time up to 15 days led to a pure AST-type material) is obtained under unstirred or stirred conditions respectively, whereas a ( $\mathrm{Si}, \mathrm{Al})$ mixture led to the RUT-type material. $\mathrm{H}^{1}$ liquid $\mathrm{NMR}$ and ${ }^{13} \mathrm{C}$ MAS NMR of the AST- and RUT-type materials are consistent with the presence of the only organic species $\mathrm{N}\left(\mathrm{CH}_{3}\right)_{4}{ }^{+}$, arising from the decomposition of the initial $\mathrm{BTMAEE}^{2+}$ ion. ${ }^{19} \mathrm{~F}$ MAS RMN shows the usual single peak at $-39 \mathrm{ppm} / \mathrm{CFCl}_{3}$, characteristic of $\mathrm{F}^{-}$ions occluded in D4R units, for the AST-type material and no signal at all for the RUT-type material. Note that Patarin et al. [20] prepared in fluoride media the RUT-type material in the presence of $\mathrm{N}\left(\mathrm{CH}_{3}\right)_{4}{ }^{+}$ions and proposed to assign the small signals observed at -58 and $-73 \mathrm{ppm} / \mathrm{CFCl}_{3}$ on the ${ }^{19} \mathrm{~F}$ MAS NMR spectrum to $\mathrm{F}^{-}$ions occluded in micropores [21]. The syntheses performed under stirred conditions at $150^{\circ} \mathrm{C}$ from purely siliceous mixtures led to the AST-type material or to the ZSM-48 zeolite, depending on the dilution of the mixture, with a $\mathrm{H}_{2} \mathrm{O} / \mathrm{SiO}_{2}$ molar ratio equal to 5 or 2 , respectively. This phase selectivity change agrees with the 

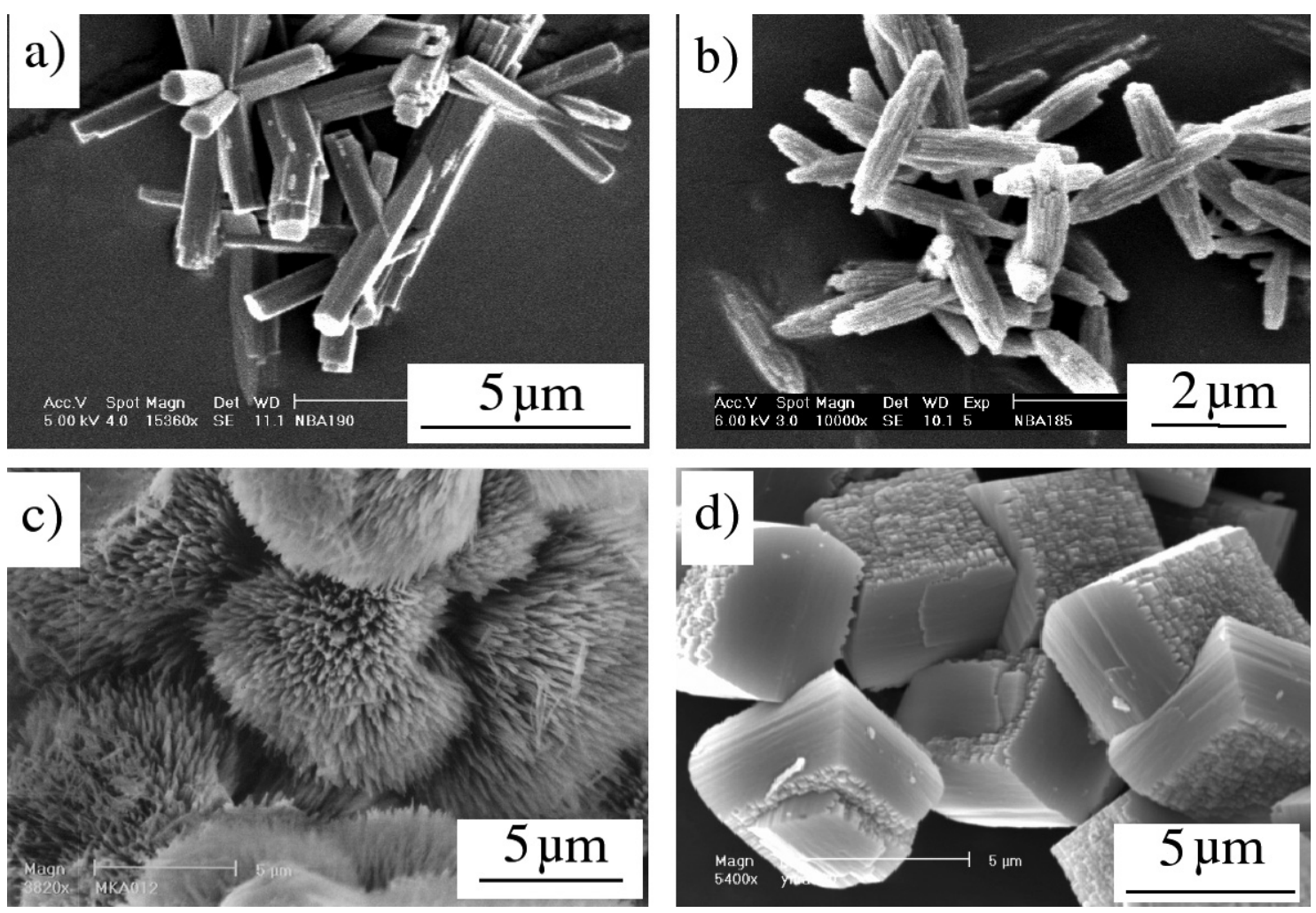

Figure 2

Scanning electron micrographs of ZSM-48 zeolite samples a) No. 2, b) 3, c) 16 and d) of beta zeolite sample No. 20.

previously reported observations in fluoride media [22-23], the formation of the less dense phase being favoured in concentrated systems. The powder X-ray diffractogramm and morphology of the ZSM-48 sample are analogous to the ones reported before (Figs. 1, 2a, b), but according to ${ }^{1} \mathrm{H}$ liquid $\mathrm{NMR}$, the BTMAEE ${ }^{2+}$ is this time the only detected organic species as expected at the lower $\mathrm{pH}$ values used in fluoride media. ${ }^{19} \mathrm{~F}$ MAS NMR spectrum of the ZSM-48 sample No. 13 (Fig. 3a) shows the presence of a main signal at around $-72 \mathrm{ppm} / \mathrm{CFCl}_{3}$, characteristic of $\mathrm{F}^{-}$ions located in the channels of zeolites [21]. According to the elementary and thermal analysis results, the formula per u.c. is close to 1.64 BTMAEE $^{2+}$; $2.3 \mathrm{~F}-$; $48 \mathrm{SiO}_{2}$ for this $\mathrm{ZSM}-48$ sample. The $\mathrm{F} / \mathrm{N}$ molar ratio is surprisingly much lower than 1 (about 0.7), which might be related to the presence of (Si-O) $)_{3} \mathrm{SiO}^{-}$defects, although such kind of defects are rarely found in pure silica zeolites prepared in fluoride media [24]. The larger amount of $\mathrm{BTMAEE}^{2+}$ per unit cell in this sample prepared in fluoride medium, in comparison to the sample obtained in hydroxide medium, must also be underlined.

In consideration of the previous observations concerning the stability, the longer $\mathrm{BTMABE}^{2+}$ cation (chloride form) was only tested in purely siliceous fluoride media at $170^{\circ} \mathrm{C}$ (Tab. 2). With increase of the $\mathrm{H}_{2} \mathrm{O} / \mathrm{SiO}_{2}$ ratio in the reaction mixture, the formation of the AST-type clathrasil, a mixture of the latter and zeolite beta, and finally ZSM-48 zeolite was observed. This selectivity change is apparently not in agreement with the usual observations [22, 23]. Actually, concentrated mixtures favour the decomposition of the $\mathrm{BTMABE}^{2+}$ ion, as evidenced by the ${ }^{1} \mathrm{H}$ NMR spectra of samples 14-16 (spectra not shown). Whereas in samples 14 and 15 a mixture of BTMAEE ${ }^{2+}$ and other degradation products (like $\mathrm{N}\left(\mathrm{CH}_{3}\right)_{4}{ }^{+}$ or $\left.\mathrm{N}\left(\mathrm{CH}_{3}\right)_{3}\right)$ is present, in the ZSM-48 sample No. 16 , the only occluded template is the $\mathrm{BTMABE}^{2+}$ cation. Figure $2 \mathrm{c}$ displays the corresponding morphology, with bundles of acicular crystals. Besides, the ${ }^{19} \mathrm{~F}$ MAS NMR spectrum of the ZSM-48 sample shows the presence of a main signal at around $-72 \mathrm{ppm} / \mathrm{CFCl}_{3}$, close to the value found before. Note finally that a slight change in the synthesis conditions (see experiments No. 16 and 17) leads to the formation of an MFI-type zeolite instead of the ZSM-48 zeolite, which might be due to a lower $\mathrm{pH}$ and/or a higher fluoride concentration.

\subsection{Syntheses in the Presence of the $n$-Diquat}

The gel composition is the following: $1 \mathrm{SiO}_{2} ; \mathrm{v}(0.125-0.5)$ $n$-diquat $(\mathrm{OH})_{2} ; y(0.25-1 \mathrm{HF}) ; z(2-10) \mathrm{H}_{2} \mathrm{O}$. The most representative syntheses are described in Table 3 and are performed at $170^{\circ} \mathrm{C}$ for 7 days under static or stirred conditions. 

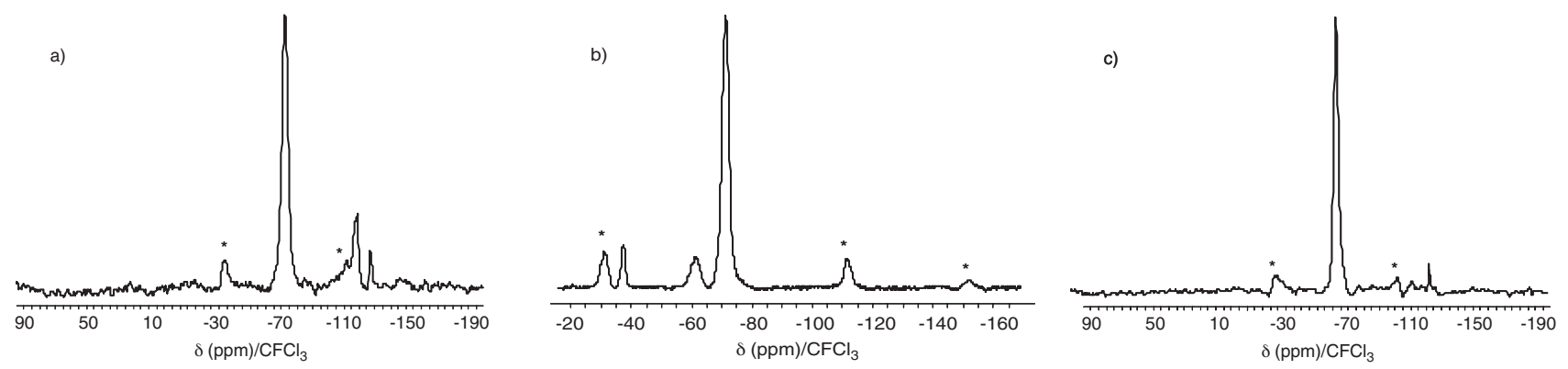

Figure 3

${ }^{19}$ F MAS NMR spectra of ZSM-48 zeolite sample No. 13 a); zeolite beta sample No. 20 b) and of MFI-type zeolite sample No. 23 c).

TABLE 2

Description of the most representative syntheses in fluoride medium in the presence of $\mathrm{BTMAEE}^{2+}$ or $\mathrm{BTMABE}^{2+}\left(1 \mathrm{SiO}_{2} ; x \mathrm{Al}_{2} \mathrm{O}_{3} ; 0.25 \mathrm{R}(\mathrm{OH})_{2} ; y \mathrm{HF} ; z \mathrm{H}_{2} \mathrm{O}\right), 7$ days

\begin{tabular}{|c|c|c|c|c|c|c|c|}
\hline OSDA & Exp. No. & $\mathrm{T}\left({ }^{\circ} \mathrm{C}\right)$ & $x$ value & $y$ value & $z$ value & Synthesis conditions & Products (XRD)* \\
\hline BTMAEE & 9 & 170 & 0 & 0.5 & 5 & unstirred & Am. \\
\hline BTMAEE & 10 & 170 & 0 & 0.5 & 5 & stirred & $48+\mathrm{AST}+\mathrm{Am}$. \\
\hline BTMAEE & 11 & 170 & 0.02 & 0.5 & 5 & stirred & RUT \\
\hline BTMAEE & 12 & 150 & 0 & 0.7 & 5 & stirred & AST \\
\hline BTMAEE & 13 & 150 & 0 & 0.7 & 2 & stirred & 48 \\
\hline BTMABE & 14 & 170 & 0 & 0.7 & 2 & stirred & AST \\
\hline ВТМАВE & 15 & 170 & 0 & 0.7 & 5 & stirred & AST + beta \\
\hline ВTMABE & 16 & 170 & 0 & 0.7 & 10 & stirred & 48 \\
\hline BTMABE & 17 & 170 & 0 & 1 & 10 & stirred & MFI \\
\hline
\end{tabular}

* 48: ZSM-48 zeolite; MFI: MFI-type zeolite; AST: AST type material; RUT: RUT-type material; Am: amorphous phase.

In the presence of diquat- 6 , the phase selectivity changes upon dilution of the system from the very open zeolite ITQ-13 $[13,14]$ to the medium-pore ZSM-48 zeolite, in agreement with previous observations $[22,23]$. In both products, ${ }^{13} \mathrm{C}$ MAS NMR and ${ }^{1} \mathrm{H}$ liquid NMR spectra (not shown) reveal that the only occluded organic species is the diquat- 6 cation. The ${ }^{19} \mathrm{~F}$ MAS NMR spectra show the presence of two signals at around $-39 \mathrm{ppm}\left(\mathrm{F}^{-}\right.$ions occluded in double four ring units) and -66 ppm in ITQ-13, and again, of one main signal at around $-72 \mathrm{ppm}$ in the ZSM-48 sample. The latter sample displays the usual acicular morphology. The weight loss up to $1000^{\circ} \mathrm{C}$ lies around $7.6 \%$ and corresponds to the cumulated amounts of diquat-6 (6.8\%) and $\mathrm{F}^{-}(0.73 \%)$. The formula per u.c. cell is thus $48 \mathrm{SiO}_{2}: 1.04$ diquat-6: 1.2 $\mathrm{F}^{-}$. The too small amount of $\mathrm{F}^{-}$ions to compensate for the positive charges of the organic cations was already observed above.

The syntheses in presence of diquat- 9 or diquat- 10 with $z=5$ lead to the beta zeolite displaying the usual square bi-pyramidal morphology (Fig. 2d). According to thermal analyses and ${ }^{1} \mathrm{H}$ NMR spectroscopy about 2 diquat cations are occluded per unit-cell, the organic weight content (about
$16.5 \%$ ) being close to the value found for zeolite beta prepared with tetraethylammonium cations [25]. The $\mathrm{F}$ //diquat molar ratio is again anomalously low, actually only slightly higher than 1, instead of being close to 2, may be due to the presence of some ${ }^{3} \mathrm{Q}$ connectivity defects. The ${ }^{19} \mathrm{~F}$ MAS NMR spectrum (Fig. 3b) display as expected two signals at -71.5 and $-59 \mathrm{ppm} / \mathrm{CFCl}_{3}$, together with a small additional signal at around $-39 \mathrm{ppm}$. The latter signal, characteristic of D4R units could be due to the presence of domains of BECtype zeolite, as already observed by Camblor et al. [26] for zeolite beta prepared with different templates. In the presence of diquat-9, a less open zeolite (MFI-type zeolite) is formed from a more diluted system $(z=10$, Exp. 23) [22, 23]. The corresponding ${ }^{19} \mathrm{~F}$ MAS NMR spectrum (Fig. 3c) shows a signal at about $-67 \mathrm{ppm} / \mathrm{CFCl}_{3}$. This value is slightly different from the value reported when the silicalite- 1 is prepared with tetrapropylammonium [27]. Note that only the diquat-9 cation is detected by the ${ }^{1} \mathrm{H}$ NMR spectroscopy. The corresponding X-ray diffractogramm is given in Figure 4 as well as a micrograph revealing a rather unusual rod-shaped morphology for this zeolite. In the most concentrated system $(z=2$, Exp. 22) the formation of the AST-type clathrasil is 
TABLE 3

Description of the most representative syntheses in fluoride medium in the presence of the $n$-diquat $\left(1 \mathrm{SiO}_{2} ; 0.25 n\right.$-diquat $\left.\left.(\mathrm{OH})_{2} ; 0.5 \mathrm{HF}\right) ; z \mathrm{H}_{2} \mathrm{O}\right), 170^{\circ} \mathrm{C}, 7$ days

\begin{tabular}{c|c|c|c|c}
\hline Experiment No. & Nature of the template & $z$ value & Synthesis conditions & Products (From XRD) \\
\hline 18 & diquat-6 & 5 & stirred & ITQ-13 \\
19 & diquat-6 & $10-20$ & unst. or stirred & ZSM-48 \\
20 & diquat-9 & 5 & unst. or stirred & beta \\
21 & diquat-10 & 5 & unst. or stirred & unstirred \\
22 & diquat-9 & 2 & unstirred & AST \\
23 & diquat-9 & 10 & stirred & MFI \\
24 & diquat-5 & $2-5$ & stirred & AST \\
25 & diquat-5 & 10 & ZSM-48 \\
\hline
\end{tabular}

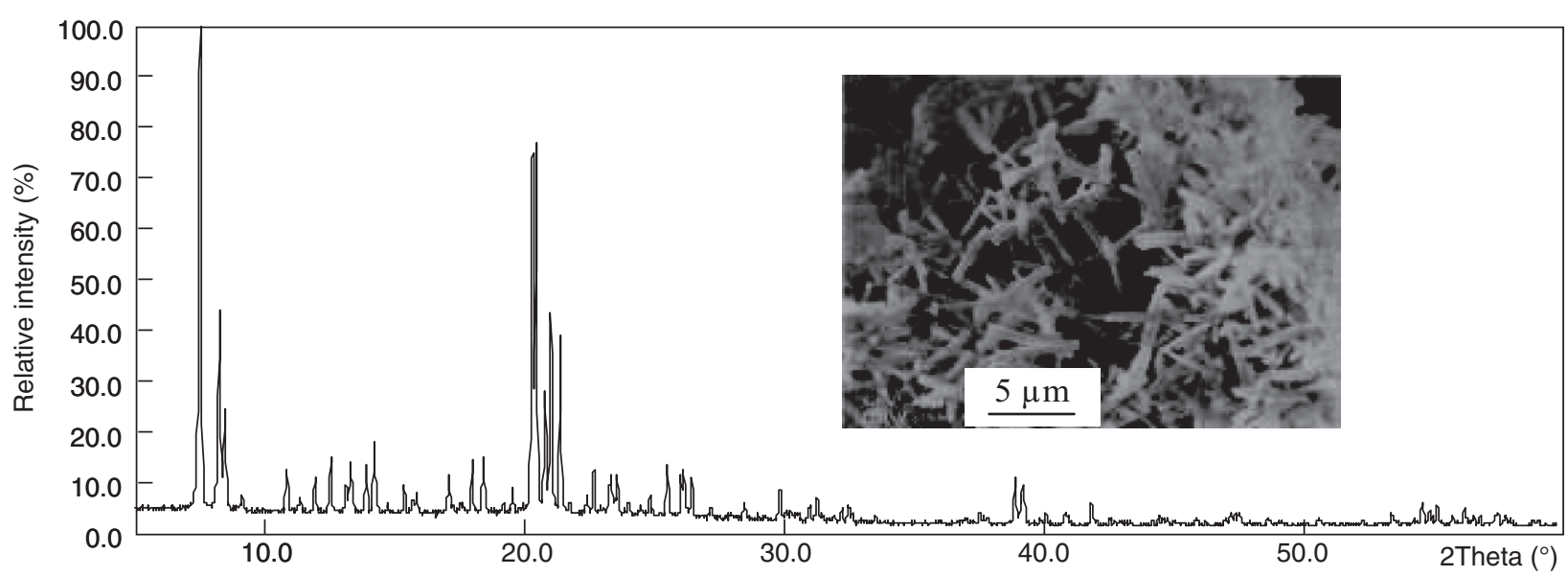

Figure 4

X-ray diffraction pattern and scanning electron micrograph of MFI-type zeolite sample No. 23.

clearly unexpected and is actually due to the fact that, under these conditions, the only evidenced occluded species are the $\mathrm{N}\left(\mathrm{CH}_{3}\right)_{4}{ }^{+}$or $\mathrm{N}\left(\mathrm{CH}_{3}\right)_{3}$ species arising from the degradation of the diquat- 9 cation.

Finally, the use of the diquat- 5 cation leads to the formation of the ZSM-48 zeolite or of the AST-type clathrasil, according to whether the system is diluted or concentrated (Exp. 25 or 24 respectively). The ${ }^{19} \mathrm{~F}$ MAS NMR spectrum of the ZSM-48 sample displays again a main characteristic signal at about $-72 \mathrm{ppm}$, the liquid ${ }^{1} \mathrm{H}$ NMR spectrum showing the presence of the only diquat- 5 species. On the contrary, in the AST-type material, only the $\mathrm{N}\left(\mathrm{CH}_{3}\right)_{4}{ }^{+}$ or $\mathrm{N}\left(\mathrm{CH}_{3}\right)_{3}$ species are evidenced by ${ }^{1} \mathrm{H}$ NMR spectroscopy.

\section{CONCLUSION}

Two new SDAs associating both the quaternary ammonium and ether chemical functions, namely the bis ( $n$-trimethylaminoethyl)ether and the bis ( $n$-trimethylaminobuthyl) ether were used in hydroxide and fluoride media. Although these templates decompose more or less strongly, depending on the synthesis conditions, they allow the crystallisation of pure ZSM-48 zeolite samples, mainly in the purely siliceous form. Used in purely siliceous systems, the 5-,6-,8- and 9-diquat cations led in fluoride media to several zeolites, namely, ZSM-48, ITH-, BEA- and MFI-type zeolites. ZSM-48 is obtained in the less concentrated systems in the presence of diquat-5 and diquat- 6 , whereas in more concentrated systems AST-type material or ITQ-13 (ITH) zeolite are obtained, respectively. The latter formation of AST-type material is related to the observed lower stability of diquat- 5 compared to diquat-6 in these conditions. Diquat-9 and diquat-10 led to beta zeolite. Concentration of the reaction mixture in the presence of diquat-9 led to the AST-type material (degradation of the template), whereas dilution of the system allows the formation of a MFI-type zeolite. The relationships between the morphological features of the templates and the porosity characteristics of the obtained zeolite (monoor tri-dimensional system of channels delimited by 10- or 12 -membered rings) are clearly very complex and are strongly influenced by the other synthesis parameters. 


\section{REFERENCES}

1 Dodwell G.D., Denkewicz R.P., Sand L.B. (1985) Zeolites 5, 153.

2 Valyocsik E.W., Page N.M. (1986) Eur. Pat. Appl. No. 0174121.

3 Casci J.L. (1986) Stud. Sci. Catal. 28, 215.

4 Valyocsik E.W. (1986) US Patent No. 4568654.

5 Moini A., Schmitt K.D., Valyocsik E.W., Polomski R.F. (1994) Zeolites 14, 504.

6 Paik W.C., Shin C.-H., Hong S.B. (2000) Chem. Commun. 1609.

7 Lee S.H., Lee D.-K., Shin C.H., Paik W.C., Lee W.M., Hong S.B. (2000) J. Catal. 196, 158.

8 Paik W.C., Shin C.H., Lee J.M., Ahn B.J., Hong S.B. (2001) J. Phys. Chem. B 105, 9994.

9 Lee S.H., Shin C.H., Choi G.J., Park T.J., Nam I.S., Han B., Hong S.B. (2003) Micropor. Mesopor. Mat. 60, 237.

10 Lee S.H., Lee D.-K., Shin C.H., Park Y.-K., Wright P.A., Lee W.M., Hong S.B. (2003) J. Catal. 215, 151.

11 Lee S.H., Shin C.-H., Hong S.B. (2003) Chem. Lett. 32, 542.

12 Lee S.H., Shin C.H., Yang D.-K., Ahn S.D., Nam I.S., Hong S.B. (2004) Micropor. Mesopor. Mat. 68, 97.

13 Boix T., Puche M., Camblor M., Corma A. (2002) US Patent No. 6471941.

14 Corma A., Puche M., Rey F., Sankar G., Teat S. (2003) Angew. Chem. Int. Edit. 42, 1156.

15 Corma A., Diaz-Cabanas M.J., Jorda J.L., Martinez C., Moliner M. (2006) Nature 443, 842.
16 Piccione P.M., Davis M.E. (2001) Micropor. Mesopor. Mat. 49, 163.

17 Smith P.A.S., Franck S. (1952) J. Am. Chem. Soc. 74, 509.

18 Morren H., Trolin S., Strubbe H., Grivsky E. (1952) J. Pharm. Belg. 7, 295.

19 Giordano G., Dewaele N., Gabelica Z., Nagy J.B., Derouane E.G. (1991) Appl. Catal. 71, 79.

20 Patarin J., Caullet P., Marler B., Faust A.C., Guth J.L. (1994) Zeolites 14, 675.

21 Koller H., Wölker A., Villaescusa L.A., DiazCabanas M.J., Valencia S., Camblor M.A. (1999) J. Am. Chem. Soc. 121, 3368.

21 Camblor M.A., Villaescusa L.A., Diaz-Cabanas M.J. (1999) Top. Catal. 9, 359.

22 Barrett P., Boix E., Camblor M.A., Corma A., Diaz-Cabanas M.J., Valencia S. (1999) Proceedings of the 15th Int. Zeol. Conf., Treacy M.M.J. et al. (eds.), Baltimore, USA, p. 1495.

23 Chézeau J.M., Delmotte L., Guth J.L., Gabélica Z. (1991) Zeolites 11, 598.

24 Camblor M.A., Corma A., Valencia S. (1998) J. Mater. Chem. 8, 2137.

25 Camblor M.A., Barrett P.A., Diaz Cabanas M.J., Villaescusa L.A., Puche M., Boix T., Perez E., Koller H. (2001) Micropor. Mesopor. Mat. 48, 11.

26 Delmotte L., Soulard M., Guth F., Seive A., Lopez A., Guth J.L. (1990) Zeolites 10, 778.

Final manuscript received in September 2007 